\title{
The Macrocyclic Peptide Natural Product CJ-15,208 Is Orally Active and Prevents Reinstatement of Extinguished Cocaine-Seeking Behavior
}

Jane V. Aldrich, ${ }^{* \dagger}$ Sanjeewa N. Senadheera, ${ }^{\dagger}$ Nicolette C. Ross, ${ }^{\ddagger}{ }^{\S}$ Michelle L. Ganno, ${ }^{\ddagger}$ Shainnel O. Eans, ${ }^{\ddagger}$ and Jay P. McLaughlin ${ }^{\ddagger}$

${ }^{\dagger}$ Department of Medicinal Chemistry, University of Kansas, Lawrence, Kansas 66045, United States

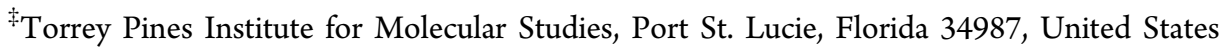

ABSTRACT: The macrocyclic tetrapeptide natural product CJ-15,208 (cyclo[Phe-D-Pro-Phe-Trp]) exhibited both dose-dependent antinociception and kappa opioid receptor (KOR) antagonist activity after oral administration. CJ-15,208 antagonized a centrally administered KOR selective agonist, providing strong evidence it crosses the blood-brain barrier to reach KOR in the CNS. Orally administered CJ-15,208 also prevented both cocaine- and stress-induced reinstatement of extinguished cocaine-seeking behavior in the conditioned place preference assay in a time- and dose-dependent manner. Thus, CJ-15,208 is a promising lead compound with a unique activity profile for potential development, particularly as a therapeutic to prevent relapse to

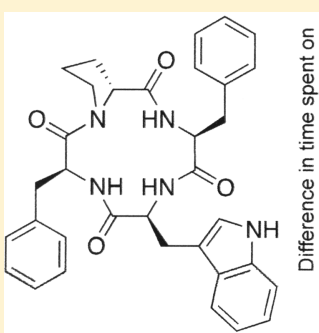

CJ-15,208

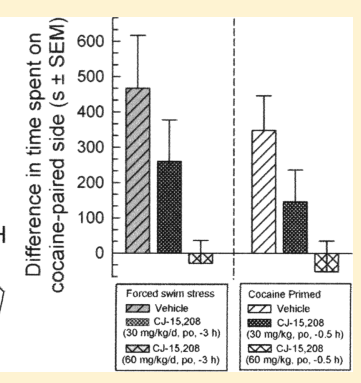

$T^{1}$ he tetrapeptide CJ-15,208 (cyclo[Phe-D-Pro-Phe-Trp]), which was isolated from the fermentation broth of the fungus Ctenomyces serratus ATCC 15502, was reported to bind preferentially to kappa opioid receptors (KOR) and to antagonize a KOR agonist in the electrically stimulated rabbit vas deferens assay. ${ }^{1}$ This macrocyclic peptide is structurally distinct from endogenous opioid peptides, as it lacks the classic tyrosine pharmacophore containing a basic amine and also the additional basic groups found in the C-terminal "address" sequence $^{2}$ of the dynorphin endogenous KOR agonists.

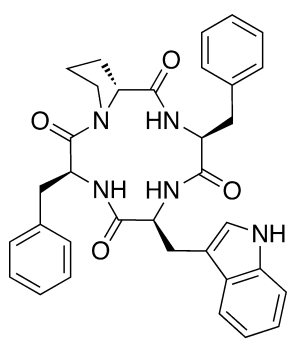

CJ-15,208

Thus CJ-15,208 provided a novel lead compound for the development of new ligands for KOR. When the natural product was originally isolated, the stereochemistry of three of the residues (D-Pro and the two Phe residues) was determined, but not that of the tryptophan residue. ${ }^{1}$ We synthesized the peptides containing $\mathrm{L}^{-}$and $\mathrm{D}-\mathrm{Trp}^{3,4}$ and found that the optical rotation of the peptide containing L-Trp was consistent with that of the natural product. However, when this L-Trpcontaining macrocyclic peptide was tested in vivo following intracerebroventricular (icv) injection, it exhibited potent antinociceptive activity in the mouse $55{ }^{\circ} \mathrm{C}$ warm-water tail- withdrawal assay mediated by KOR and mu opioid receptors (MOR), followed by KOR antagonist activity at later time points. ${ }^{5}$ The D-Trp peptide also binds preferentially to KOR with similar affinity to that of the natural product, ${ }^{3-6}$ but in contrast to the $\mathrm{L}$-Trp peptide exhibits primarily KOR antagonist activity in vivo. ${ }^{5}$ Other macrocyclic peptides have also demonstrated opioid activity. Structurally related macrocyclic pentapeptides (cyclo[Tyr-X-D-Trp-Phe-Y]), designed as cyclic analogues of the linear MOR endogenous agonist endomorphin 1 , have been reported with affinity and efficacy at $\mathrm{MOR}^{7,8}$ and recently with affinity for $\mathrm{KOR}^{8}$

The physiochemical properties of CJ-15,208, specifically its macrocyclic structure and relatively low molecular weight (577 $\mathrm{Da})$, suggested it would be a promising lead compound expected to exhibit activity after oral administration. In contrast to linear peptides, which are generally metabolized rapidly by proteases, macrocyclic peptides are typically stable to proteases and instead can be metabolized by cytochrome $\mathrm{P}_{450}$ enzymes involved in drug metabolism., ${ }^{9,10}$ Their macrocyclic structure also often promotes intramolecular hydrogen bonding, which can facilitate membrane permeability, ${ }^{11}$ thereby enhancing oral bioavailability and penetration of the blood-brain barrier into the central nervous system (CNS). The immunosuppressant drug cyclosporine is active after oral administration, providing precedent for the oral activity of macrocyclic peptides.

Building on our previous results, ${ }^{5} \mathrm{CJ}-15,208$ was evaluated in mice after oral administration in three assays: the $55^{\circ} \mathrm{C}$ warm-

Special Issue: Special Issue in Honor of Lester A. Mitscher

Received: October 5, 2012

Published: January 17, 2013 
water tail-withdrawal assay for antinociceptive and KOR antagonist activity, the rotorod assay for locomotor effects, and a conditioned place preference (CPP) assay for its ability to block reinstatement of extinguished cocaine-seeking behavior. Herein it is reported that the oral administration of CJ-15,208 produces dose-dependent antinociception and KOR antagonist activity and prevents reinstatement of cocaine-seeking behavior induced by exposure to either stress or cocaine.

\section{RESULTS AND DISCUSSION}

In order to obtain sufficient macrocyclic peptide for evaluation after oral administration, the synthesis and purification of CJ15,208 was modified ${ }^{12}$ with changes made in the key cyclization reaction and purification procedure. The linear peptide TrpPhe-D-Pro-Phe was cyclized at $30{ }^{\circ} \mathrm{C}$ for $24 \mathrm{~h}$ after $12 \mathrm{~h}$ at room temperature. Purification by normal-phase flash chromatography rather than reversed-phase HPLC ${ }^{12}$ greatly facilitated purification of the larger quantities of the peptide required for evaluation in vivo following oral administration; with these two modifications $>400 \mathrm{mg}$ of pure macrocyclic peptide $(75 \%$ yield) was obtained.

The macrocyclic peptide was initially evaluated in vivo in the $55{ }^{\circ} \mathrm{C}$ warm-water tail-withdrawal antinociceptive assay to assess its agonist and antagonist activity after oral administration. CJ-15,208 exhibited antinociceptive activity with an $\mathrm{ED}_{50}$ value (and 95\% confidence interval) of 3.49 (1.98-5.73) $\mathrm{mg} / \mathrm{kg}$, po (per os) $40 \mathrm{~min}$ after administration (Figure 1),

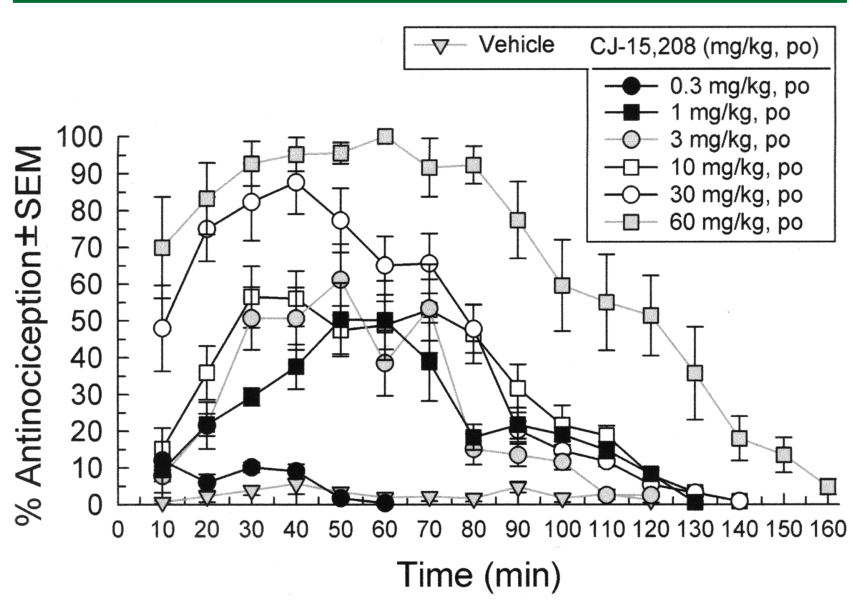

Figure 1. Antinociceptive activity of CJ-15,208 following oral administration to $\mathrm{C} 57 \mathrm{BL} / 6 \mathrm{~J}$ mice using the $55{ }^{\circ} \mathrm{C}$ warm-water tailwithdrawal assay with repeated measurement over time. Administration of vehicle (1:1:8) alone had no significant effect. The mean \% antinociception \pm SEM from 7 to 24 mice per group is presented.

consistent with its demonstrated opioid agonist activity after icv administration. ${ }^{5}$ Over the first hour, CJ-15,208 exhibited a significant interaction of dose and time $\left(F_{(36,480)}=4.25, p<\right.$ 0.05 ; repeated measures analysis of variance, ANOVA), reaching peak antinociception within $40 \mathrm{~min}$ that did not significantly decline by $60 \mathrm{~min}$. Neither vehicle nor the $0.3 \mathrm{mg} /$ $\mathrm{kg}$ dose was efficacious during this time. Over the second hour, CJ-15,208 again demonstrated significant interactions of dose and time $\left(F_{(25,250)}=5.35, p<0.05\right.$; repeated measures ANOVA), but with reductions in antinociception such that by $120 \mathrm{~min}$, post-treatment tail-withdrawal latencies after $1,3,10$, or $30 \mathrm{mg} / \mathrm{kg}$, po CJ-15,208 did not significantly differ from the vehicle. Notably, the highest dose $(60 \mathrm{mg} / \mathrm{kg}$, po) produced more prolonged antinociceptive activity ( $>140 \mathrm{~min}$ ), which was significantly greater than the 10 or $30 \mathrm{mg} / \mathrm{kg}$ doses $\left(F_{(2,29)}=\right.$ 11.89, $p<0.05$; one-way ANOVA).

The ability of CJ-15,208 to antagonize the antinociceptive activity of the KOR-selective agonist U50,488 (( \pm )-trans-3,4dichloro- $N$-methyl- $N$-[2-(1-pyrrolidinyl)cyclohexyl]benzeneacetamide) was then assessed following oral administration of the macrocyclic peptide (Figure 2). As expected, CJ-

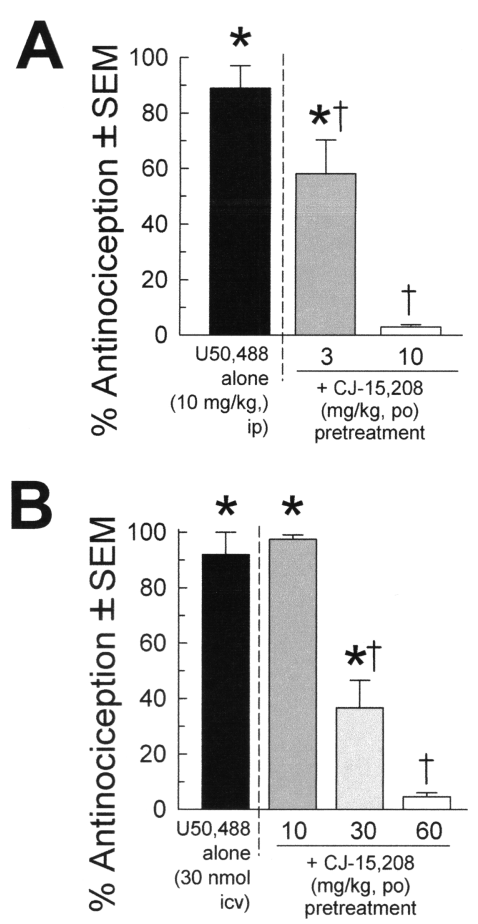

Figure 2. Oral administration of $\mathrm{CJ}-15,208$ produced dose-dependent antagonism of U50,488-induced antinociception administered (A) peripherally (ip) and (B) centrally (icv) in the mouse $55{ }^{\circ} \mathrm{C}$ warmwater tail-withdrawal assay. Mice were pretreated with CJ-15,208 $3 \mathrm{~h}$ prior to antinociceptive testing with U50,488. The mean \% antinociception \pm SEM from 8 mice per group is presented; $*=$ significantly different from the baseline tail-withdrawal latency; $\dagger=$ significantly different from antinociception induced by U50,488 alone; one-way ANOVA with Tukey HSD post hoc test.

15,208 antagonized peripherally administered U50,488 [10 mg/ $\mathrm{kg}$, through the intraperitoneal (ip) route] in a dose-dependent fashion (Figure 2A), with significant antagonism at doses of both 3 and $10 \mathrm{mg} / \mathrm{kg}$, po $\left(F_{(3,51)}=64.41, p<0.0001\right.$; one-way ANOVA). To assess whether CJ-15,208 could penetrate the blood-brain barrier to reach KOR in the CNS, the ability of the macrocyclic peptide to antagonize centrally administered U50,488 was then evaluated. Oral administration of CJ-15,208 $3 \mathrm{~h}$ prior to analgesic testing dose-dependently antagonized the antinociceptive effect of icv U50,488 (30 nmol, Figure 2B) at doses of 30 and $60 \mathrm{mg} / \mathrm{kg}$, po $\left(F_{(4,63)}=139.7, p<0.0001\right.$; oneway ANOVA), providing strong evidence that this macrocyclic peptide can cross the blood-brain barrier.

KOR-selective agonists are known to produce sedative effects through activation of $\mathrm{KOR}^{13}$ To assess whether the KOR agonist activity of CJ-15,208 5 would produce sedative effects that could confound analysis in the antinociceptive or conditioned place preference assays (see below), the macrocyclic peptide was evaluated in the rotorod assay (Figure 3 ). As expected, the KOR-selective agonist U50,488 (10 mg/kg, ip) 


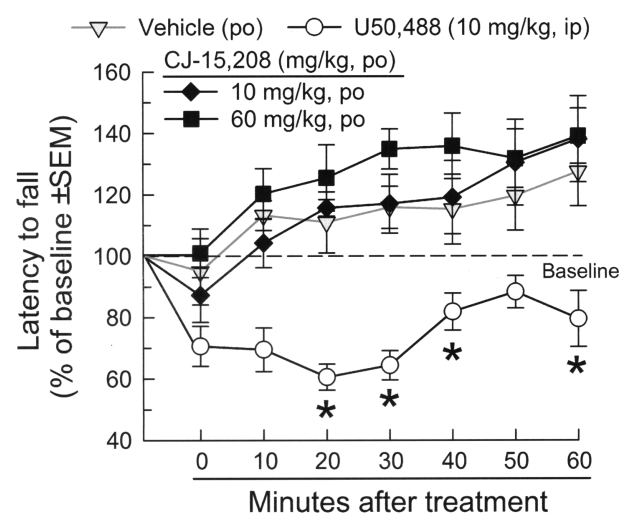

Figure 3. CJ-15,208 was without locomotor effect in the mouse rotorod assay. Mice were orally administered vehicle, CJ-15,208 (10 or $60 \mathrm{mg} / \mathrm{kg}$, po), or U50,488 (10 mg/kg, ip). Latency to fall \pm SEM is presented as the mean percent change from baseline performance for 7 or 8 mice per treatment group; $*=$ significantly different from matching vehicle response.

caused a significant reduction $\left(F_{(4,232)}=30.55, p<0.0001\right.$; twoway ANOVA) in the latency to fall from the rotating rod compared to vehicle at several time points, consistent with the sedative effects of centrally active KOR agonists. In contrast, mice treated with $\mathrm{CJ}-15,208$ at 10 or $60 \mathrm{mg} / \mathrm{kg}$, po did not exhibit significant differences in the latency to fall compared to vehicle-treated animals. Thus, orally administered CJ-15,208 does not appear to produce the sedation typically seen with KOR-selective agonists such as U50,488.

$\mathrm{KOR}$ and its endogenous agonists the dynorphins play an important role in the response to stress ${ }^{14-16}$ and are thought to mediate reinstatement of cocaine-seeking behavior following extinction. ${ }^{17,18}$ A number of KOR antagonists have been shown to prevent reinstatement of extinguished cocaine-seeking behavior, ${ }^{18-22}$ including the structurally related KOR antagonist [D-Trp]CJ-15,208 (cyclo[Phe-D-Pro-Phe-D-Trp]). ${ }^{5}$ Since CJ-15,208 produced KOR antagonist activity, the ability of oral pretreatment with CJ-15,208 to prevent stress-induced reinstatement of extinguished cocaine CPP was evaluated. Following four days of cocaine place conditioning, mice showed a significant preference for the cocaine-paired chamber $\left(F_{(10,467)}\right.$ $=11.34 ; p<0.0001$; one-way ANOVA with Tukey honestly significant difference (HSD) post hoc test; Figure 4, black bar). Extinction was observed within 3 weeks of place conditioning, at which point mice were pretreated orally once daily for two days with vehicle $(1: 1: 8)$ or CJ-15,208 (30 or $60 \mathrm{mg} / \mathrm{kg}$, po) 3 $\mathrm{h}$ before exposure to forced swimming stress (see diamonds in schematic, Figure 4A). The duration of pretreatment was chosen to correspond to CJ-15,208-mediated KOR antagonist activity in the CNS (see Figure 2B). Consistent with its KOR antagonism, CJ-15,208 prevented stress-induced reinstatement of cocaine CPP at $60(p<0.05$, Tukey HSD post hoc test $)$ but not $30 \mathrm{mg} / \mathrm{kg}$, po (Figure $4 \mathrm{~B}$ ).

KOR agonists block acute cocaine self-administration, suppress the rewarding effects of cocaine in animal models, ${ }^{23-28}$ and are not themselves reinforcing. ${ }^{29,30}$ Acute administration of KOR agonists has also been shown to prevent the cocaine-primed reinstatement of extinguished cocaineseeking behavior. ${ }^{31-33}$ Since CJ-15,208 initially demonstrated finite KOR agonist activity, it was examined for its ability to prevent cocaine-induced reinstatement of cocaine CPP at a time point $(30 \mathrm{~min})$ when it exhibited agonist activity in the
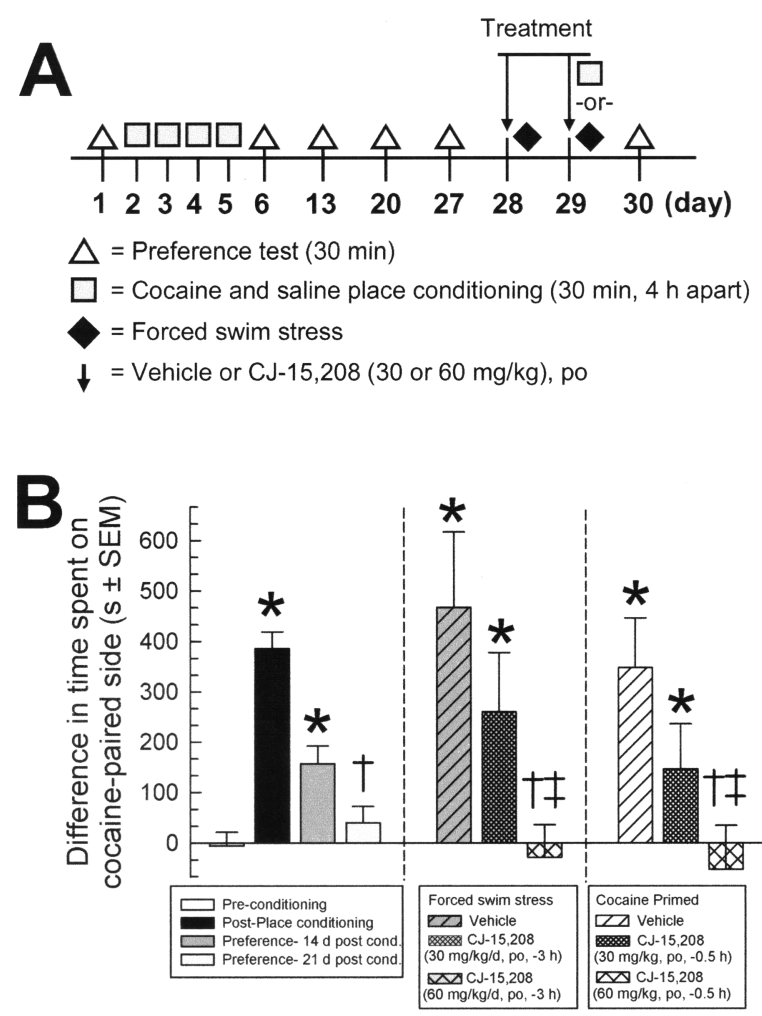

Figure 4. Dose-dependent prevention of reinstatement of cocaine CPP following oral pretreatment with CJ-15,208. (A) Schematic of reinstatement and testing protocol. Vehicle (1:1:8, po) or CJ-15,208 $(30$ or $60 \mathrm{mg} / \mathrm{kg}$, po) was administered on days 28 and $29,3 \mathrm{~h}$ prior to exposure to forced swim stress (diamonds). For cocaine-primed reinstatement the mice were also treated on days 28 and 29 with vehicle or CJ-15,208, followed by cocaine place conditioning $30 \mathrm{~min}$ later on day 29 (square). (B) Mice exhibited significant preference for the cocaine $(10 \mathrm{mg} / \mathrm{kg}$, sc, daily for 4 days)-paired compartment, with extinction occurring 3 weeks later (left bars). Mice were then exposed to forced swim stress (center bars) or an additional round of cocaine place conditioning (right bars), resulting in the reinstatement of place preference in vehicle-treated mice (hashed bars). Pretreatment with CJ-15,208 (middle bars) $3 \mathrm{~h}$ prior to forced swimming prevented stress-induced reinstatement of place preference, and pretreatment 30 min prior to cocaine conditioning (right bars) prevented cocaineprimed reinstatement of cocaine CPP. Mean difference in time spent on the drug-paired side \pm SEM is presented for 12 to 16 mice per treatment condition; cocaine place conditioning data on left represent combined responses of 96 mice used in this experiment; $*=$ significantly different from preconditioning place preference response (leftmost bar), $\dagger=$ significantly different from post-CPP response (leftmost black solid bar); $\neq=$ significantly different from stressinduced or cocaine-primed reinstatement of place preference response (center and right); ANOVA followed by Tukey HSD post hoc test.

antinociceptive assay (Figure 1). Mice demonstrating extinction of cocaine CPP were pretreated orally once daily for two days with vehicle $(1: 1: 8)$ or CJ-15,208 (30 or $60 \mathrm{mg} / \mathrm{kg}$, po) and exposed to an additional cycle of cocaine place conditioning on day 29 (see square in schematic, Figure 4A). When administered orally $30 \mathrm{~min}$ prior to cocaine, CJ-15,208 prevented cocaine-induced reinstatement of cocaine CPP ( $p$ $<0.05$, Tukey HSD post hoc test, only after pretreatment with $60 \mathrm{mg} / \mathrm{kg}$, po). Notably, pretreatment with CJ-15,208 (60 mg/ $\mathrm{kg} / \mathrm{d}$, po, for $2 \mathrm{~d}$ ) did not induce reinstatement in mice demonstrating extinction of cocaine CPP where saline was substituted for the additional cycle of cocaine place 
conditioning (final preference $=-304 \pm 71 \mathrm{~s}, n=8 ; p>0.05$, not significant; Tukey HSD post hoc test).

The ability of CJ-15,208 to prevent both stress- and cocaineinduced reinstatement of extinguished cocaine-seeking behavior is an unusual property of this macrocyclic peptide; to our knowledge this is the first report of an opioid ligand that can block both of these causes of reinstatement to cocaine-seeking behavior. Compounds possessing only KOR antagonist activity have not been shown to prevent cocaine-primed reinstatement of cocaine-seeking behavior. ${ }^{5,19-21}$ Reports suggest that KORselective agonists produce dysphoria ${ }^{34}$ and can actually reinstate extinguished cocaine-seeking behavior. ${ }^{17,18}$ It seems likely that the unique profile of CJ-15,208 in preventing both triggers of reinstatement is due to the distinctive mixed KOR/ MOR agonist and KOR antagonist activity of this natural product. Mixed-action KOR/MOR agonists such as the benzomorphans ethylketocyclazocine and 8-carboxamidocyclazocine acutely decrease cocaine self-administration. ${ }^{35,36}$ Likewise, buprenorphine, a mixed MOR partial agonist/KOR antagonist, has been shown to reduce cocaine self-administration $^{37,38}$ and drug (but not stress)-induced reinstatement. ${ }^{39}$

In conclusion, CJ-15,208 demonstrated both agonist (antinociception) and KOR antagonist activity following oral administration. Such a demonstration of biological activity by a peptide after oral administration is relatively rare. ${ }^{40}$ The ability of orally administered CJ-15,208 to antagonize centrally administered KOR agonist provides strong evidence that this macrocyclic peptide crosses the blood-brain barrier to reach KOR in the CNS. In contrast to U50,488, CJ-15,208 does not decrease the latency to fall in the rotorod test, suggesting that it is not producing hypolocomotor effects. At pretreatment times correlating with agonist (antinociceptive) and KOR antagonist activity in the antinociceptive assay, orally administered CJ15,208 prevented cocaine- and stress-induced reinstatement, respectively, of extinguished cocaine-seeking behavior in the CPP assay. These results suggest this macrocyclic peptide natural product is a promising lead compound for potential treatment of drug abuse, especially for preventing relapse.

\section{EXPERIMENTAL SECTION}

Materials. Reagents for peptide synthesis were obtained from the following sources: Fmoc (fluorenylmethoxycarbonyl)-protected amino acids, 2-chlorotrityl chloride resin, and coupling reagents HATU (2(1H-7-azabenzotriazol-1-yl)-1,1,3,3-tetramethyluronium hexafluorophosphate) and $\mathrm{PyBOP}$ (benzotriazol-1-yloxytripyrrolidinophosphonium hexafluorophosphate) were obtained from Novabiochem (EMD), San Diego, CA, USA; 1-hydroxybenzotriazole and $\mathrm{N}, \mathrm{N}$ diisopropylethylamine were from Fluka, Milwaukee, WI, USA; trifluoroacetic acid was purchased from Pierce, Rockford, IL, USA; and HPLC-grade solvents were from Fisher Scientific, Pittsburgh, PA, USA. HPLC analysis was performed on a Vydac $218 T P \mathrm{C}_{18}$ reversedphase column (Grace Davison, $4.6 \times 50 \mathrm{~mm}, 5 \mu \mathrm{m}$ ). Compounds other than CJ-15,208 used in pharmacological assays were obtained from Sigma, St. Louis, MO, USA.

Synthesis of CJ-15,208. The linear peptide precursor Trp-Phe-DPro-Phe was synthesized by Fmoc solid-phase synthesis on the 2chlorotrityl chloride resin by procedures described previously. ${ }^{3,4,41}$ The crude linear peptide was cyclized by a modification of a previously published procedure. ${ }^{12}$ The crude linear peptide $(300 \mathrm{mg}, 0.50 \mathrm{mmol})$ in $\mathrm{N}, \mathrm{N}$-dimethylformamide (DMF, $20 \mathrm{~mL}$ ) was added dropwise at a rate of $1.2 \mathrm{~mL} / \mathrm{h}$ (using a $\mathrm{KD}$ Scientific single infusion syringe pump) to a dilute solution of HATU ( $288 \mathrm{mg}, 0.75 \mathrm{mmol}, 1.5$ equiv) and $\mathrm{N}, \mathrm{N}$-diisopropylethylamine $(700 \mu \mathrm{L}, 4.0 \mathrm{mmol}, 8$ equiv $)$ in DMF ( 800 $\mathrm{mL})$ over $6 \mathrm{~h}$. After $6 \mathrm{~h}$, additional HATU $(288 \mathrm{mg}, 0.75 \mathrm{mmol}, 1.5$ equiv) was added to the reaction in one portion, and additional linear peptide $(300 \mathrm{mg}, 0.50 \mathrm{mmol})$ in DMF $(20 \mathrm{~mL})$ was added dropwise at a rate of $1.2 \mathrm{~mL} / \mathrm{h}$, as described above. The reaction was then stirred for $12 \mathrm{~h}$ at room temperature, followed by an additional $24 \mathrm{~h}$ at $30^{\circ} \mathrm{C}$. The solvent was evaporated under reduced pressure at $37^{\circ} \mathrm{C}$, and the crude macrocyclic tetrapeptide was redissolved in toluene $(3 \times 25 \mathrm{~mL})$ and evaporated to dryness. The resulting residue was dissolved in EtOAc $(100 \mathrm{~mL})$, and the organic phase washed sequentially with $1 \mathrm{~N}$ citric acid, saturated $\mathrm{NaHCO}_{3}$ solution, and brine $(3 \times$ each). The organic phase was dried over anhydrous $\mathrm{MgSO}_{4}$, and the filtrate evaporated under reduced pressure to give the crude macrocyclic tetrapeptide, which was purified by silica gel chromatography using a step gradient solvent system [EtOAc-hexane $(3: 2,100 \mathrm{~mL})$, EtOAchexane $(7: 3,100 \mathrm{~mL})$, EtOAc-hexane $(4: 1,100 \mathrm{~mL})$, EtOAc-hexane $(9: 1,200 \mathrm{~mL})$, EtOAc $(100 \%, 200 \mathrm{~mL})$, and $1 \% \mathrm{MeOH}$ in EtOAc $(200 \mathrm{~mL})]$ to afford pure $c y c l o[$ Phe-D-Pro-Phe-Trp], which was then lyophilized from aqueous $\mathrm{MeCN}$ to give the peptide as a white solid (436 mg, 75\% yield): ${ }^{1} \mathrm{H}$ NMR (500 MHz, $\left.\mathrm{CD}_{3} \mathrm{COCD}_{3}\right) \delta 9.92(1 \mathrm{H}$, s, NH-Trp), $7.66(1 \mathrm{H}, \mathrm{d}, J=6.8 \mathrm{~Hz}$, aryl CH/NH), $7.60(1 \mathrm{H}, \mathrm{d}, J=$ $10.2 \mathrm{~Hz}$, aryl CH/NH), $7.52(1 \mathrm{H}, \mathrm{d}, J=7.9 \mathrm{~Hz}$, aryl CH/NH$), 7.38-$ $7.20(10 \mathrm{H}, \mathrm{m}, \operatorname{aryl~} \mathrm{CH} / \mathrm{NH}), 7.10-7.04(2 \mathrm{H}, \mathrm{m}, \operatorname{aryl~CH}), 7.03-6.96$ $(2 \mathrm{H}, \mathrm{m}$, aryl $\mathrm{CH}), 6.84(1 \mathrm{H}, \mathrm{d}, J=1.6 \mathrm{~Hz}$, aryl $\mathrm{CH} / \mathrm{NH}), 5.15-5.13$ $\left(1 \mathrm{H}, \mathrm{m}, \mathrm{Phe}^{1} \alpha \mathrm{H}\right), 4.72(1 \mathrm{H}, \mathrm{d}, J=6.6 \mathrm{~Hz}$, Pro $\alpha \mathrm{H}), 4.60-4.55(1 \mathrm{H}$, m, Phe $\left.^{3} \alpha \mathrm{H}\right), 3.99-3.95(1 \mathrm{H}, \mathrm{m}, \operatorname{Trp} \alpha \mathrm{H}), 3.77-3.71(1 \mathrm{H}, \mathrm{m}$, Pro $\delta$ $\mathrm{H}), 3.57(1 \mathrm{H}, \mathrm{dd}, J=14.7,8.8 \mathrm{~Hz}, \operatorname{Trp} \beta \mathrm{H}), 3.50(1 \mathrm{H}, \mathrm{dd}, J=14.7$, $7.9 \mathrm{~Hz}, \operatorname{Trp} \beta \mathrm{H}), 3.34-3.26(1 \mathrm{H}, \mathrm{m}, \operatorname{Pro} \delta \mathrm{H}), 3.22(1 \mathrm{H}, \mathrm{dd}, J=13.6$, $\left.8.4 \mathrm{~Hz}, \mathrm{Phe}^{1} \beta \mathrm{H}\right), 3.15\left(1 \mathrm{H}, \mathrm{dd}, J=13.7,9.0 \mathrm{~Hz}, \mathrm{Phe}^{3} \beta \mathrm{H}\right), 3.02$ $\left(1 \mathrm{H}, \mathrm{dd}, J=13.6,7.2 \mathrm{~Hz}, \operatorname{Phe}^{1} \beta \mathrm{H}\right), 2.91-2.86\left(1 \mathrm{H}, \mathrm{m}, \mathrm{Phe}^{3} \beta \mathrm{H}\right)$, $2.29-2.20(1 \mathrm{H}, \mathrm{m}$, Pro $\beta \mathrm{H}), 2.02-1.96(1 \mathrm{H}, \mathrm{m}$, Pro $\gamma \mathrm{H}), 1.80-1.74$ $(1 \mathrm{H}, \mathrm{m}, \operatorname{Pro} \beta \mathrm{H}), 1.70-1.63(1 \mathrm{H}, \mathrm{m}$, Pro $\gamma \mathrm{H}) ;{ }^{13} \mathrm{C}$ NMR $(125 \mathrm{MHz}$, $\left.\mathrm{CD}_{3} \mathrm{COCD}_{3}\right) \delta 175.0$ (CO, Trp), 174.4 (CO, $\left.\mathrm{Phe}^{3}\right), 173.9$ (CO, $\mathrm{Phe}^{1}$ ), 172.0 (CO, Pro), 138.6 (ipso C, Phe ${ }^{3}$ ), 138.4 (ipso C, Phe ${ }^{1}$ ), 137.6 (C, Trp-bridge carbon between 1 and 7), $130.2\left(\mathrm{CH}, \mathrm{Phe}^{3}\right.$ meta), $130.1\left(\mathrm{CH}, \mathrm{Phe}^{1}\right.$ meta $), 129.4\left(\mathrm{CH}, \mathrm{Phe}^{3}\right.$ ortho $), 129.3(\mathrm{CH}$, $\mathrm{Phe}^{1}$ ortho), 128.2 (C, Trp-bridge carbon between ipso $\mathrm{C}$ and 4), 127.5 (CH, Phe ${ }^{1}$ para and Phe ${ }^{3}$ para), $124.4(\mathrm{CH}$, Trp-2), $122.2(\mathrm{CH}$, Trp6), 119.6 (CH, Trp-5), 119.0 (CH, Trp-4), $112.3(\mathrm{CH}, \operatorname{Trp}-7), 111.2$ (ipso C, Trp), $61.7(\mathrm{CH}, \operatorname{Trp} \alpha), 58.4(\mathrm{CH}$, Pro $\alpha), 56.8\left(\mathrm{CH}, \mathrm{Phe}^{3}\right.$ $\alpha), 54.0\left(\mathrm{CH}, \mathrm{Phe}^{1} \alpha\right), 47.1\left(\mathrm{CH}_{2}\right.$, Pro $\left.\delta\right) 37.0\left(\mathrm{CH}_{2}, \mathrm{Phe}^{3} \beta\right), 36.9$ $\left(\mathrm{CH}_{2}, \mathrm{Phe}^{1} \beta\right), 26.3\left(\mathrm{CH}_{2}, \operatorname{Trp} \beta\right), 25.5\left(\mathrm{CH}_{2}\right.$, Pro $\left.\beta\right), 25.3\left(\mathrm{CH}_{2}\right.$, Pro $\gamma)$; MS (ESI (+)) $m / z$ calcd for $\left[\mathrm{C}_{34} \mathrm{H}_{35} \mathrm{~N}_{4} \mathrm{O}_{5}+\mathrm{Na}\right]^{+} 600.2587$, found 600.2560; HPLC $t_{\mathrm{R}}=12.6 \mathrm{~min}(20-85 \% \mathrm{MeCN}$ over 45 min with $0.1 \%$ TFA $)$ and $t_{\mathrm{R}}=18.4 \mathrm{~min}(30-70 \% \mathrm{MeOH}$ over $45 \mathrm{~min}$ with $0.1 \%$ TFA), flow rate $1.0 \mathrm{~mL} / \mathrm{min}$, purity $>99 \%$ in both HPLC systems.

Animals and Compound Administration. Adult male C57BL/ $6 \mathrm{~J}$ mice weighing 20-25 g, obtained from Jackson Laboratories (Bar Harbor, ME, USA), were used for these studies because of their established responses to analgesics, ${ }^{42}$ stress, and cocaine place conditioning. $^{14,20,21}$ All mice were kept on a $12 \mathrm{~h}$ light-dark cycle and were housed in accordance with the National Institutes of Health Guide for Care and Use of Laboratory Animals. CJ-15,208 was dissolved daily prior to administration in ethanol and Tween 80 , and warm (40 ${ }^{\circ} \mathrm{C}$ ) saline added to give a final vehicle consisting of 1 part ethanol, 1 part Tween 80 , and 8 parts sterile saline (0.9\%), referred to as 1:1:8. This vehicle has been used to solubilize other hydrophobic opiates for in vivo studies. ${ }^{43,44}$ U50,488 was administered in $0.9 \%$ sterile saline.

Antinociceptive Assay. The $55{ }^{\circ} \mathrm{C}$ warm-water tail-withdrawal assay was performed in mice as previously described, ${ }^{5}$ with the latency of tail withdrawal from the water taken as the end point. After determining baseline tail-withdrawal latencies, mice were administered CJ-15,208 po in the 1:1:8 vehicle. A cutoff time of $15 \mathrm{~s}$ was used in this study; if the mouse failed to display a tail-withdrawal response during that time, the tail was removed from the water and the animal was assigned a maximal antinociceptive score of $100 \%$. At each time point, antinociception was calculated according to the formula:

\%antinociception $=100 \times[($ test latency - control latency $)$

$$
/(15-\text { control latency })]
$$

For evaluation of its antagonist activity CJ-15,208 was administered orally, followed $3 \mathrm{~h}$ later (when CJ-15,208-induced agonist activity had 
dissipated) by either an ip $(10 \mathrm{mg} / \mathrm{kg})$ or icv $(30 \mathrm{nmol})$ injection of U50,488. The mice were then evaluated 40 and 20 min later, respectively, in the $55{ }^{\circ} \mathrm{C}$ warm-water tail-withdrawal assay as described above.

Rotorod Assay. Both possible sedative and hyperlocomotor effects of CJ-15,208 were assessed by rotorod performance, as modified from previous protocols. ${ }^{45}$ Following seven habituation trials (the last utilized as a baseline measure of rotorod performance), mice were administered vehicle $(1: 1: 8)$ or CJ-15,208 (10 or $60 \mathrm{mg} / \mathrm{kg}$, po) orally or U50,488 $(10 \mathrm{mg} / \mathrm{kg}$, ip $)$ and assessed in accelerated speed trials (180 s maximum latency at $0-20 \mathrm{rpm}$ ) over a $60 \mathrm{~min}$ period. Decreased latencies to fall in the rotorod test indicate impaired motor performance. Vehicle-treated animals exhibited significantly increased latencies to fall over time in this assay $\left(F_{(6,183)}=3.562, p=0.0023\right.$; two-way ANOVA with Tukey HSD post hoc test; Figure 3), consistent with improved mastery of the task over time. Data are expressed as the percent change from baseline performance.

Reinstatement of Cocaine Conditioned Place Preference. Mice were conditioned following a counterbalanced cocaine CPP paradigm using similar timing to that reported previously. ${ }^{20,21,45}$ The amount of time mice spent in each of three compartments was measured over a 30 min testing period; prior to conditioning animals exhibited an average preference difference of $-6 \pm 27 \mathrm{~s}$ for the (eventual) drug- vs saline-paired compartments. For each of the next four days mice were administered $0.9 \%$ saline and consistently confined in a randomly assigned outer compartment for $30 \mathrm{~min}$, half of each group in the right chamber and half in the left compartment. Four hours later mice were subcutaneously (sc) administered cocaine (10 $\mathrm{mg} / \mathrm{kg}$ ) and confined to the opposite compartment for $30 \mathrm{~min}$ (see Figure 4A). Mice were then tested twice weekly over a 3-week period until extinction was established (triangles; Figure 4A). Extinction is defined as a statistically significant difference in time spent during the trial in the cocaine-paired compartment compared to the initial response after cocaine place conditioning.

Following demonstration of extinction, reinstatement of cocaine CPP was evaluated after exposure to forced swim stress or an additional cycle of cocaine place conditioning (diamonds and square, respectively; Figure 4A) as described previously. ${ }^{5,20,21}$ Mice were pretreated orally with either 1:1:8 vehicle or CJ-15,208 (30 or $60 \mathrm{mg}$ / $\mathrm{kg}$, po) on two consecutive days $3 \mathrm{~h}$ prior to forced swim stress, performed as described previously, ${ }^{5,20,21}$ to produce stress-induced reinstatement of cocaine CPP. Additional mice were pretreated similarly on days 28 and 29 (see Figure 4A), and 30 min after the final administration on day 29 were subjected to a further cycle of cocaine place conditioning. An additional set of mice received saline place conditioning instead of cocaine treatment on day 29. On the following day (day 30) all groups of mice were evaluated for place preference; data are presented as the difference in time spent in the drug- and vehicle-associated chambers.

Statistical Analysis. Student's $t$ tests and ANOVA with Tukey's HSD post hoc test were used as appropriate to analyze tail-withdrawal data. ${ }^{5}$ Tail withdrawal latency was assessed via separate repeated measures ANOVA at $10 \mathrm{~min}$ intervals for hour 1 (baseline through 60 min) and hour 2 (70 through $120 \mathrm{~min}$ ). Doses that had activity beyond this time frame were analyzed separately via one-way ANOVA. All interactions were followed up with post-hoc analyses to determine group differences. Rotorod data were analyzed via repeated measures ANOVA, using drug treatment condition as a between-groups factor. For all repeated measures ANOVAs simple main effects and simple main effect contrasts are presented following significant interactions. Conditioned place preference data were analyzed via one-way ANOVA using the difference in time spent in the treatment- vs vehicleassociated sides as the dependent measure and conditioning status as the between-groups factor.

\section{AUTHOR INFORMATION}

\section{Corresponding Author}

*Tel: (785) 864-2287. Fax: (785) 864-5326. E-mail: jaldrich@ ku.edu.

\section{Present Address}

${ }^{\S}$ Scripps Research Institute, Jupiter, Florida, United States. Notes

The authors declare no competing financial interest.

\section{ACKNOWLEDGMENTS}

This work was supported by NIDA grants DA023924 and DA032928 (to J.V.A.) and the State of Florida, Executive Office of the Governor's Office of Tourism, Trade, and Economic Development (to J.P.M.).

\section{DEDICATION}

Dedicated to Dr. Lester A. Mitscher, of the University of Kansas, for his pioneering work on the discovery of bioactive natural products and their derivatives.

\section{REFERENCES}

(1) Saito, T.; Hirai, H.; Kim, Y.-J.; Kojima, Y.; Matsunaga, Y.; Nishida, H.; Sakakibara, T.; Suga, O.; Sujaku, T.; Kojima, N. J. Antibiot. 2002, 55, 847-854.

(2) Chavkin, C.; Goldstein, A. Proc. Natl. Acad. Sci. U. S. A. 1981, 78, 6543-6547.

(3) Kulkarni, S. S.; Ross, N. C.; McLaughlin, J. P.; Aldrich, J. V. Adv. Exp. Med. Biol. 2009, 611, 269-270.

(4) Ross, N. C.; Kulkarni, S. S.; McLaughlin, J. P.; Aldrich, J. V. Tetrahedron Lett. 2010, 51, 5020-5023.

(5) Ross, N. C.; Reilley, K. J.; Murray, T. F.; Aldrich, J. V.; McLaughlin, J. P. Br. J. Pharmacol. 2012, 165, 1097-1108.

(6) Dolle, R. E.; Michaut, M.; Martinez-Teipel, B.; Seida, P. R.; Ajello, C. W.; Muller, A. L.; DeHaven, R. N.; Carroll, P. J. Bioorg. Med. Chem. Lett. 2009, 19, 3647-3650.

(7) Cardillo, G.; Gentilucci, L.; Tolomelli, A.; Spinosa, R.; Calienni, M.; Qasem, A. R.; Spampinato, S. J. Med. Chem. 2004, 47, 5198-5203.

(8) Gentilucci, L.; Tolomelli, A.; De Marco, R.; Spampinato, S.; Bedini, A.; Artali, R. ChemMedChem 2011, 6, 1640-1653.

(9) Christians, U.; Sewing, K. F. Pharmacol. Ther. 1993, 57, 291-345.

(10) Delaforge, M.; Andre, F.; Jaouen, M.; Dolgos, H.; Benech, H.; Gomis, J. M.; Noel, J. P.; Cavelier, F.; Verducci, J.; Aubagnac, J. L.; Liebermann, B. Eur. J. Biochem. 1997, 250, 150-157.

(11) Rezai, T.; Bock, J. E.; Zhou, M. V.; Kalyanaraman, C.; Lokey, R. S.; Jacobson, M. P. J. Am. Chem. Soc. 2006, 128, 14073-14080.

(12) Senadheera, S. N.; Kulkarni, S. S.; McLaughlin, J. P.; Aldrich, J. V. In Peptides: Building Bridges. Proceedings of the 22nd American Peptide Symposium, Lebl, M., Ed.; American Peptide Society: San Diego, CA, 2011; pp 346-347.

(13) Riviere, P. J. Br. J. Pharmacol. 2004, 141, 1331-1334.

(14) McLaughlin, J. P.; Marton-Popovici, M.; Chavkin, C. J. Neurosci. 2003, 23, 5674-5683.

(15) Shirayama, Y.; Ishida, H.; Iwata, M.; Hazama, G. I.; Kawahara, R.; Duman, R. S. J. Neurochem. 2004, 90, 1258-1268.

(16) Wee, S.; Koob, G. F. Psychopharmacology 2010, 210, 121-135.

(17) Valdez, G. R.; Platt, D. M.; Rowlett, J. K.; Rüedi-Bettschen, D.; Spealman, R. D. J. Pharmacol. Exp. Ther. 2007, 323, 525-533.

(18) Redila, V. A.; Chavkin, C. Psychopharmacology 2008, 200, 5970.

(19) Beardsley, P. M.; Howard, J. L.; Shelton, K. L.; Carroll, F. I. Psychopharmacology 2005, 183, 118-126.

(20) Carey, A. N.; Borozny, K.; Aldrich, J. V.; McLaughlin, J. P. Eur. J. Pharmacol. 2007, 569, 84-89.

(21) Aldrich, J. V.; Patkar, K. A.; McLaughlin, J. P. Proc. Natl. Acad. Sci. U. S. A. 2009, 106, 18396-18401.

(22) Beardsley, P. M.; Pollard, G. T.; Howard, J. L.; Carroll, F. I. Psychopharmacology 2010, 210, 189-198.

(23) Suzuki, T.; Shiozaki, Y.; Masukawa, Y.; Misawa, M.; Nagase, H. Jpn. J. Pharmacol. 1992, 58, 435-442.

(24) Glick, S. D.; Maisonneuve, I. M.; Raucci, J.; Archer, S. Brain Res. 1995, 681, 147-152. 
(25) Negus, S. S.; Mello, N. K. Exp. Clin. Psychopharmacol. 1999, 7, $307-317$.

(26) Mori, T.; Nomura, M.; Nagase, H.; Narita, M.; Suzuki, T. Psychopharmacology 2002, 161, 17-22.

(27) Shippenberg, T. S.; Zapata, A.; Chefer, V. I. Pharmacol. Ther. 2007, 116, 306-321.

(28) Aldrich, J. V.; McLaughlin, J. P. AAPS J. 2009, 11, 312-322.

(29) Koob, G. F.; Vaccarino, F. J.; Amalric, M.; Bloom, F. E. NIDA Res. Monogr. 1986, 71, 146-164.

(30) McLaughlin, J. P.; Land, B. B.; Li, S.; Pintar, J. E.; Chavkin, C. Neuropsychopharmacology 2006, 31, 787-794.

(31) Schenk, S.; Partridge, B.; Shippenberg, T. S. Psychopharmacology 1999, 144, 339-346.

(32) Morani, A. S.; Kivell, B.; Prisinzano, T. E.; Schenk, S. Pharmacol., Biochem. Behav. 2009, 94, 244-249.

(33) Rüedi-Bettschen, D.; Rowlett, J. K.; Spealman, R. D.; Platt, D. M. Psychopharmacology 2010, 210, 169-177.

(34) Walsh, S. L.; Strain, E. C.; Abreu, M. E.; Bigelow, G. E. Psychopharmacology 2001, 157, 151-162.

(35) Bowen, C. A.; Negus, S. S.; Zong, R.; Neumeyer, J. L.; Bidlack, J. M.; Mello, N. K. Neuropsychopharmacology 2003, 28, 1125-1139.

(36) Stevenson, G. W.; Wentland, M. P.; Bidlack, J. M.; Mello, N. K.; Negus, S. S. Eur. J. Pharmacol. 2004, 506, 133-141.

(37) Mello, N. K.; Lukas, S. E.; Kamien, J. B.; Mendelson, J. H.; Drieze, J.; Cone, E. J. J. Pharmacol. Exp. Ther. 1992, 260, 1185-1193.

(38) Kuzmin, A. V.; Gerrits, M. A.; Zvartau, E. E.; van Ree, J. M. Eur. Neuropsychopharmacol. 2000, 10, 447-454.

(39) Sorge, R. E.; Rajabi, H.; Stewart, J. Neuropsychopharmacology 2005, 30, 1681-1692.

(40) Aldrich, J. V.; McLaughlin, J. P. Drug Discovery Today Technol. 2012, 9, e23-e31.

(41) Aldrich, J. V.; Kulkarni, S. S.; Senadheera, S. N.; Ross, N. C.; Reilley, K. J.; Eans, S. O.; Ganno, M. L.; Murray, T. F.; McLaughlin, J. P. ChemMedChem 2011, 6, 1739-1745.

(42) Wilson, S. G.; Smith, S. B.; Chesler, E. J.; Melton, K. A.; Haas, J. J.; Mitton, B.; Strasburg, K.; Hubert, L.; Rodriguez-Zas, S. L.; Mogil, J. S. J. Pharmacol. Exp. Ther. 2003, 304, 547-559.

(43) Schmidt, M. D.; Schmidt, M. S.; Butelman, E. R.; Harding, W. W.; Tidgewell, K.; Murry, D. J.; Kreek, M. J.; Prisinzano, T. E. Synapse 2005, 58, 208-210.

(44) Wang, Y.; Tang, K.; Inan, S.; Siebert, D.; Holzgrabe, U.; Lee, D. Y.; Huang, P.; Li, J. G.; Cowan, A.; Liu-Chen, L. Y. J. Pharmacol. Exp. Ther. 2005, 312, 220-230.

(45) Paris, J. J.; Reilley, K. J.; McLaughlin, J. P. J. Addiction Res. Ther. 2011, S4. 